\title{
VLIV ENVIRONMENTÁLNÍ VÝKONNOSTI PODNIKU NA VÝKONNOST EKONOMICKOU
}

\author{
Markéta Klímková, Jana Hornungová
}

\begin{abstract}
Klíčová slova:
Životní prostř̌edí, environmentální výkonnost, výkonnost, ekonomická výkonnost, měření, environmentální indikátory, ekonomické indikátory.
\end{abstract}

Key words:

Environmental, environmental performance, performance, economic performance, measuring, environmental indicators, economic indicators.

\begin{abstract}
Abstrakt
Př́spěvek s názvem "Vliv environmentální výkonnosti podniku na výkonnost ekonomickou" se zaměřuje především na podrobný popis environmentální výkonnosti podniku a na její následnou souvztažnost s výkonnosti ekonomickou. Data pro vypracování tohoto článku byla získána na základě specifického výzkumu. Metodou sběru dat bylo dotazníkové šetření v rámci specifického výzkumu č. FP - J-10-2 na fakultě Podnikatelské VUT v Brně s názvem „Integrace environmentální, ekonomické a sociální výkonnosti podniku: Empirická analýza českých malých a středních podniků (MSP)“. Článek obsahuje cenné informace v oblasti environmentální výkonnosti a její vazby na výkonnost ekonomickou.
\end{abstract}

\begin{abstract}
The paper called "The Impact of environmental performance of enterprises on economic performance" is focused mainly on the detailed description of the environmental performance of the company and its subsequent correlation with economic performance. The data for the preparation of this article was obtained from the specific research. The method of data collection was the survey research elaborated during the specific research No. FP - J-10-2 at the Faculty of Business, BUT "Integrating environmental, economic and social business performance: An empirical analysis of Czech small and medium sized enterprises (SMEs)." The article contains valuable information about environmental performance and its links to economic performance.
\end{abstract}

\section{Úvod}

Narůstající význam ochrany životního prostř̌edí má vliv na všechny činnosti podniků, a to nejen v České republice. Podniky se tomuto novodobému trendu musejí přizpůsobit a dá se říci, že se nejedná o žádnou snadnou záležitost. Tento příspěvek má za cíl poukázat na souvztažnost mezi výkonností spojenou s ochranou životního prostředí, respektive environmentální výkonností a ekonomickou výkonností, která odráží aktivity podniku, které směřují k odstranění jeho negativních dopadů na životní prostředí, popřípadě vedou kudržení si určitého standardu, vyplývajícího z udržitelného rozvoje podniku. Jednotlivé subjekty jako individualisti mají sice malý dopad na životní prostředí, ale kombinace jejich aktivit představuje účinek značný. Proto nelze s určitostí říci, že pouze velké podniky mohou mít velký vliv na životní prostř̌edí. Na základě dotazníkového šetření, které bylo provedeno $\mathrm{v}$ rámci specifického výzkumu, budou v následujícím textu prezentovány výsledky vlivu environmentální výkonnosti na výkonnost ekonomickou. Toto zhodnocení vychází z činností malých a středních podniků na území České republiky. 


\section{Environmentální výkonnost}

Životní prostředí je nedílnou součástí života lidí. Lidská společnost byla s prostředím kolem sebe od pradávna sžita a chápala jej jako součást sebe sama. Př́roda lidem poskytovala a stále poskytuje vše, co k životu potřebují. V posledních stoletích však lidé jako by zapomněli, že nejde jen z prrírody brát, ale že je důležité změnit své chování a začít se o ni starat. Novodobý trend však ukazuje změnu k lepšímu. Lidé si uvědomují nutnost ochrany životního prostředí, jehož jsou součástí. V hodnocení ochrany životního prostředí je nevyhnutelné pohlížet na problémy a jejich řešení jak z hlediska úzkého pomocí krátkodobých finančních efektů, tak také z hlediska širšího, které zahrnuje skutečné přínosy blahobytu společnosti a dlouhodobé rozvojové předpoklady ekonomiky a kvalitativního rozvoje společnosti. Zásadní roli hraje nejen uplatňování principu prevence a předběžné opatrnosti, ale i rozvoj technologií a znalostí, které jsou produktem investic do lidského kapitálu. Politika podniků by měla vycházet $\mathrm{z}$ těchto principů $\mathrm{s}$ kladením důrazu na globální odpovědnost $\mathrm{v}$ podmínkách světového obchodu a globalizace.

Podstatou činností, vedoucích k ochraně životního prostředí, je efektivně fungující hospodářství, prosazování přístupu udržitelného rozvoje, konkurenceschopnost na globálních trzích a environmentální standardy EU. Ochrana životního prostředí je determinována efektivně dokončenou plnou transformací, podmínkami jednotného vnitřního trhu EU, globálními a konkurenčními podmínkami rozvoje hospodářství a vývojem podmínek ve světovém obchodě (Kocmanová a kol, 2010).

Jak již bylo řečeno, společnost svým působením a činnostmi neustále ovlivňuje prostředí kolem sebe. Vliv společnosti na životní prostředí se posuzuje především z pohledu množství škodlivých činností, které na něj vyvíjí. Čím lépe se podnik k životnímu prostředí bude chovat, tím vyšší bude mít environmentální výkonnost. V opačném případě, čím více škody firma na životním prostředí způsobí, tím bude její environmentální výkonnost horší. Veškeré dopady chování společnosti na životní prostředí se analyzují po jednotlivých jeho složkách. Dalo by se tedy říci, že v tomto případě vstupuje do popředí významnost jednotlivých environmentálních ukazatelů. Mezi tyto indikátory patří např́klad využití půdy nebo zdrojů, únik škodlivých látek do ovzduší, vody a půdy během celého životního cyklu produktu aj. Míra vlivu na životní prostředí vyžaduje kompletní identifikaci všech komponent podniku, měření výkonnosti s ohledem na jednotlivé složky a kombinaci měření na vektor indexů nebo jeden celkový indikátor (Schaltegger, Wagner, 2006).

Každý indikátor v sobě zahrnuje velké množství kombinací oblastí životního prostředí. Jediný takovýto indikátor vyžaduje, aby byl relativní význam různých vlivů na životní prostředí posuzován z hlediska jejich váhy. Existují studie, které měří vliv na životní prostředí podle toho, zda podnik využívá systém environmentálního managementu nebo si pouze ustanovil v rámci podniku odpovědnou osobu, která spravuje vliv působení činnosti podniku na jeho okolí a poskytuje zprávu o vztahu firmy k životnímu prostředí. Měření na základě eliminování činnosti podniku ve vztahu k ŽP nemusí dávat správný obraz o vlivu podniku na něj. Daný vliv se v této studii měří množstvím peněz vynaložených na jeho ochranu. Nastává zde však problém s určením výše nákladů, které souvisejí s eliminací proekologických činností. Mnohé nákladové položky jsou vynechávány, pokud vykazování těchto nákladů a znalostí o jejich existenci je omezené, např. dopady kvality výrobků a regulačních zpoždění, řízení času stráveného nad otázkami o dané problematice aj. (Schaltegger, Wagner, 2006).

Neustálý tlak na ochranu životního prostředí ovlivňuje i každodenní činnosti podniků. Průmyslové inženýrství je frakce inženýrství, která se zaměřuje na zlepšování procesů, přes 
řízení lidí, operací a technologií. Pro maximalizaci efektivity, výkonnosti, výroby a informačních systémů se používají velice často matematické modely. Činnosti, spojené s průmyslovým inženýrstvím, mohou vytvářet aktivní přístup ke snížení dopadu na životní prostředí. Další nástroje, běžně používané v průmyslovém inženýrství, jako například analytické techniky, se používají pro lepší rozhodování a řešení problémů. Na základě těchto technik je možné určit životaschopné a efektivní kombinace, které povedou k optimálnímu řešení (Taubitz, 2010).

Pro hodnocení environmentální výkonnosti jsou také velmi důležité informace o environmentálním profilu podniku. Informace o environmentálním profilu jsou sice v podstatě $\mathrm{u}$ každého podniku $\mathrm{k}$ dispozici, ale $\mathrm{v}$ řadě podniků nejsou propojeny $\mathrm{s}$ informacemi hodnotovými. V rámci udržitelnosti je nutné znát přínosy $\mathrm{z}$ environmentálního profilu pro obchodní, ekonomickou i sociální oblast, vliv environmentálních aspektů a dopadů podniku na výsledky hospodaření, na finanční situaci, na výkonnost podniku apod. V rámci rozhodovacích procesů v podniku jsou důležité informace o materiálových a energetických tocích a s nimi spojených environmentálních nákladech. Environmentální náklady jsou v podnicích považovány za režijní náklady a nejsou odlišeny od jiných nákladů. V souvislosti se zaváděním environmentálních systémů je tendence tyto environmentální náklady alokovat a stanovit strategie, jak je snížit. Východiskem pro alokaci environmentálních nákladů je využití životního cyklu výrobku z environmentálního hlediska.

Environmentální profil charakterizuje přístup podniku k životnímu prostředí. Aktivity podniku mohou vyvolat různé environmentální dopady (jak v oblasti využívání zdrojů, tak v oblasti vypouštění škodlivin do vzduchu, vody či půdy).

Environmentální problémy, které s podnikovými činnostmi souvisejí nebo jsou činnostmi podniku vyvolány, mohou být řešeny různým způsobem (různým přístupem i různými opatřeními). Př́istup podniku k řešení environmentálních problémů i realizovaná opatření mají velmi úzkou vazbu na ekonomickou výkonnost podniku a vyvolávají rozdílné reakce zainteresovaných stran (Kocmanová a kol., 2010).

\section{Ekonomická výkonnost}

Ekonomická výkonnost - pojem, se kterým se v současné době stále více setkáváme nejen v podnikové oblasti, ale také v běžném životě. Ekonomové, management podniků či jiní specialisté diskutují převážně nad hodnocením ekonomické výkonnosti podniků. Momentálně je čím dál tím více kladen důraz na zjištění, zda je podnik schopen zvyšovat svou hodnotu a poskytnout tak odpovídající výnos z investice věřitelů. Za základní cíl většiny podniků je obecně považována maximalizace a zvyšování tržní hodnoty $\mathrm{v}$ delším časovém období. Ekonomickou výkonnost podniku je však zapotřebí dále analyzovat a hodnotit. Právě pro tento účel bylo vytvořeno velké množství nejrůznějších metod. V praxi asi nejběžnější a nejpoužívanější metodou je hodnocení finanční a ekonomické výkonnosti podniku pomocí fundamentální nebo technické analýzy, která hodnotí podnik právě z ekonomického hlediska na základě podrobného studia a analýzy účetních výkazů (Fischer, 1992).

Jednou neznámou je však otázka, jak tuto ekonomickou výkonnost měřit. Právě v souvislosti se zaváděním systému měření výkonnosti (Performance Measurement System) se jako nejčastější členění ukazatelů jeví dělení přístupů hodnocení výkonnosti pomocí ,finančních a nefinančních ukazatelü“, jak se shoduje mnoho českých i zahraničních autorů (Ittner a kol., 2003; Dixon a kol., 1990; Pavelková, Knápková, 2009; Synek a kol., 2009). Základem je zcela jistě sledování finanční výkonnosti. 
Z klasických ukazatelů měření ekonomické výkonnosti je možno zmínit následující skupiny ukazatelů, které se při hodnocení ekonomické výkonnosti využívají: ukazatele výsledku hospodaření, ukazatele hotovostních toků a ukazatele rentability. Tyto ukazatele se však vyznačují určitými nedostatky, mezi které bychom mohli zahrnout:

- Finanční ukazatele jsou příliš historické.

- Poskytují málo informací o příčinách a řešení problémů.

- Neumějí zachytit klíčové obchodní změny.

- Některým činnostem podniku věnují minimální pozornost, např. vlivu prostředí, inovacím apod. (Synek, 2008).

Finanční indikátory tak předkládají zprávu o činnostech v podniku, která bývá peněžně vyjádřena. Pokud je však kladen stále větší důraz na ostatní činnosti, které probíhají v rámci jiných aktivit podniku, a které mohou mít na jeho chod významný vliv, je zapotřebí spolu s finančními indikátory sledovat také nefinanční ukazatele. Ty jsou v rámci měření výkonnosti uváděny pod moderními ukazateli a jako nejznámější představitel této skupiny je velmi často prezentován ukazatel EVA neboli Ekonomická přidaná hodnota. Jeho oblíbenost spočívá převážně v tom, že kombinuje hospodářský výsledek s velikostí rizika, které je velmi často spojeno s dosahováním tohoto výsledku (Mařík, Maříková, 2001).

Pro posouzení ekonomické situace se používá celá řada indikátorů, které se liší podle účelu použití. U ekonomických ukazatelů se velmi často setkáváme s problémem, kterým je tzv. komplexní pohled na danou problematiku. $\mathrm{V}$ tomto případě není vhodné se zaměřit pouze na údaje, vyplývající z účetních výkazů, je zapotřebí do propočtů zahrnout prvky nejistoty, převedené na jejich současnou hodnotu. Proto je za jeden z nejpropracovanějších ukazatelů ekonomické výkonnosti považován ukazatel EVA (Economic Value Added), jelikož nahlíží na podnikovou ekonomickou výkonnost ve vztahu k hodnotě podniku (Hyršlová, 2009). Vhodné je tedy spojení jak klasických, tak moderních ekonomických indikátorů.

\section{Vliv environmentální výkonnosti na ekonomickou výkonnost}

Podniky vesměs usilují o minimalizaci nákladů svých operací. To je zvláště významné ve vztahu k výkonnosti podniku, se kterou jsou propojeny materiální vstupy. V současné době dochází ke snižování přírodních zdrojů, jejichž zásoba je mnohdy ovlivněna činností podniků, zvláště, co se produkovaného odpadu týče. $Z$ tohoto důvodu se podniky potýkají se stále se zpř́ísnuující legislativou, která vede ke zvýšení cen při nakládání s odpady. Eliminace těchto ztrát přispívá jednak $\mathrm{k}$ hospodářsky úspěšnému chodu podniku, jednak zlepšuje environmentální aspekty jeho činnosti. V důsledku toho se mnoho podniků soustředí na strategii minimalizace odpadů již po řadu let a dosahuje tak rychlé návratnosti investic při nakládání s odpadem.

Současně s rozvojem environmentální legislativy aplikuje státní správa k dosažení ochrany životního prostředí rostoucí měrou i ekonomické nástroje. Ekonomické nástroje mají za úkol nasměrovat volbu spotřebitele nebo jiné zainteresované osoby na variantu, která je z hlediska životního prostředí výhodnější a šetrnější, a to za pomoci legislativy. Státní správa tedy přispívá k urychlení strukturální změny, která povede ke zvýšení environmentální účinnosti v ekonomice jako celku.

Ekonomické nástroje politiky vycházejí z principu ekonomické odpovědnosti za škody na životním prostředí. Ekonomickými nástroji jsou poplatky, daně, různé finanční podpory, 
depozitně refundační systémy, obchodovatelná emisní povolení, environmentální pojištění a další.

Zavádění ekonomických nástrojů politiky životního prostředí by mělo předcházet pečlivé posouzení oblasti environmentální politiky, oblasti ekonomických souvislostí, oblasti správních problémů, a dále zhodnocení všech faktorů, které jsou významné (Kocmanová a kol.).

\section{Metodika výzkumu a jeho výsledky}

Na fakultě Podnikatelské jsme se přihlásily do specifického výzkumu č. FP - J-10-2 s názvem „Integrace environmentální, ekonomické a sociální výkonnosti podniku: Empirická analýza českých malých a středních podniků (MSP)“, jehož řešení vycházelo z podrobné analýzy dotazníkového šetření, při kterém byly osloveny podniky v celé České republice bez rozlišení velikosti. Z navráceného vzorku dotazníku byly vyselektovány pouze malé a střední podniky, které byly cílem celého výzkumu. Jednotlivé podniky byly dotazovány prostřednictvím elektronické pošty, přičemž bylo odesláno 1000 dotazníků. Vyplněné dotazníky byly vyhodnoceny na začátku roku 2011 a na celém šetření se podílely autorky článku.

Jak vyplývá z názvu výzkumu, byl dotazník zaměřen na všechny tři oblasti výkonnosti podniku. Obsahoval přes 50 otázek, které měly za úkol zjistit informace z jednotlivých oblastí. Obsáhlost dotazníku byla chápána firmami jako negativní. Návratnost použitelných dotazníků byla pouze 5\%. Tento fakt byl zaprríčiněn nedostatečnou ochotou firem vyplnit všechny otázky. Některé části byly vyplněny pouze sporadicky nebo vůbec, a proto tyto dotazníky nemohly být použity. Použitelnost byla stanovena na základě předem ujednané podmínky, která vycházela z nutnosti vyplnění každé části dotazníku. Pokud dotazník měl vyplněnou každou část, byl zařazen do dalšího dotazníkového šetření. V rámci této podmínky bylo po důkladném šetření příchozích dotazníků vybráno pouze 50 firem, jejichž výsledky se pro účely výzkumu daly použít a byly věrohodné. Tento příspěvek je zaměřen na vliv environmentální výkonnosti na výkonnost ekonomickou. Proto bude následující text vycházet z vyhodnocených informací, týkajících se této oblasti.

První otázkou, kterou jsme se zabývaly, byly environmentální indikátory, ovlivňující výkonnost podniku. Oslovených podniků jsme se dotazovaly, které z uvedených ukazatelů považují za ty, které mají přímý vliv na celkovou výkonnost podniku. Jednotlivé odpovědi na tuto otázku jsou zachyceny v Grafu č. 1 . 


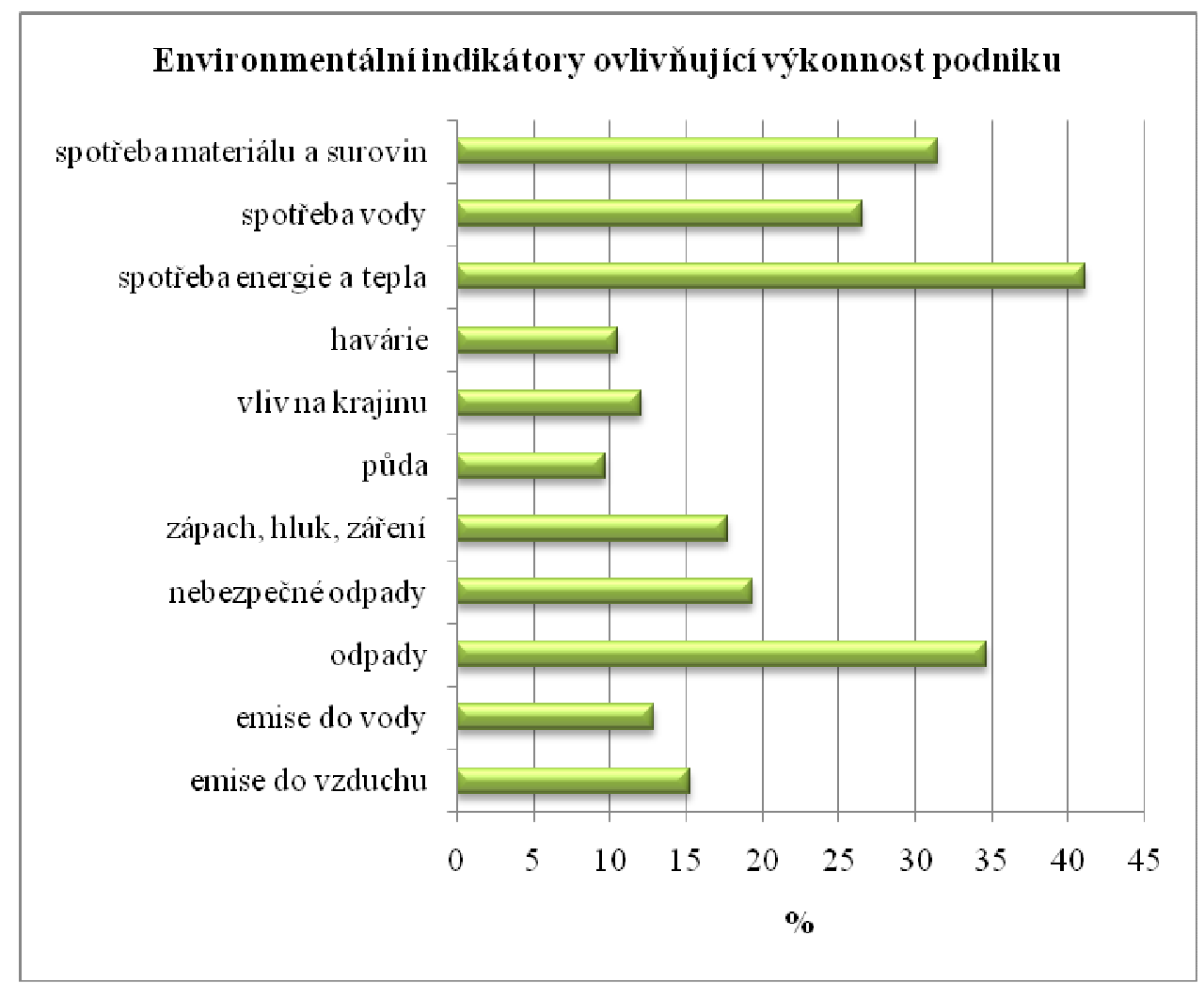

Graf 1: Environmentální indikátory ovlivňující výkonnost podniku

Z Grafu č. 1 lze vyčíst, že se podniky snaží zvyšovat svou výkonnost především snížením spotřeby energií a tepla. Tato snaha o snižování spotřeby energií plyne také s určitostí z neustálého zvyšování jejich cen. Podniky jsou tak nuceny sledovat a evidovat jak spotřebu energie, tak i tepla, jelikož cílem je snižování spotřeby těchto energií. Důvodem je převážně zachování cen výrobků na již dané úrovni. Neustálé zvyšování cen produktů by vedlo k nižší spotřebě a tím pádem nižší produkci, což je zcela jistě nevyhovující.

Mezi další tři environmentální ukazatele, na které se podniky zaměřují, patří snaha o snižování spotřeby vody, materiálu a surovin a v neposlední řadě také neustálá eliminace odpadu. Spotřeba materiálů a surovin zcela jistě souvisí s předchozím, nejčastěji sledovaným indikátorem. Sledování tohoto ukazatele je důležité z hlediska stanovení ceny produkti̊ a také $\mathrm{v}$ rámci hospodárnosti podniku. Je zapotřebí mít přehled jak o jednotlivých nákupech materiálů, tak také o jeho výdeji, jelikož v tomto př́ípadě se může stát, že celou výkonnost podniku negativně ovlivní lidský faktor, a to v potencionálním „,rozkrádání“ majetku a tím pádem jeho nevyužití k obchodní činnosti podniku. Podniky se v současnosti také potýkají s velkou produkcí odpadů, které se snaží eliminovat recyklací popřípadě opakovaným použitím aj. Odpady v sobě zahrnují velké množství nákladů, které mohou být podniky využity efektivněji. Důvodem ke sledování odpadů je také legislativní rámec (zákon č. 185/2001 Sb., o odpadech a o změně některých dalších zákonů).

Druhou oblastí našeho výzkumu, jež vyplývá ze samotného názvu článku, je vliv environmentální výkonnosti na výkonnost ekonomickou. Jak již bylo uvedeno, ekonomickou výkonnost je možno sledovat na základě finančních či nefinančních ukazatelů. V našem případě je žádoucí sledovat určitou finanční náročnost, která nastává z důvodu environmentálních opatření. Zavádění inovací v této oblasti či dodatečné sledovaní určitých ukazatelů je zcela jistě finančně náročná záležitost, tudíž je vhodné, aby podniky sledovaly jak prŕínosy těchto opatření, tak vynaložené náklady, které s tímto souvisejí. V Grafu č. 2 lze 
vidět, jak podniky odpovídaly na otázku, zda jim určitým způsobem snižování vlivu na životní prostředí ušetřilo finanční prostředky, které právě souvisejí se snižováním nákladů na energii, redukci odpadů aj.

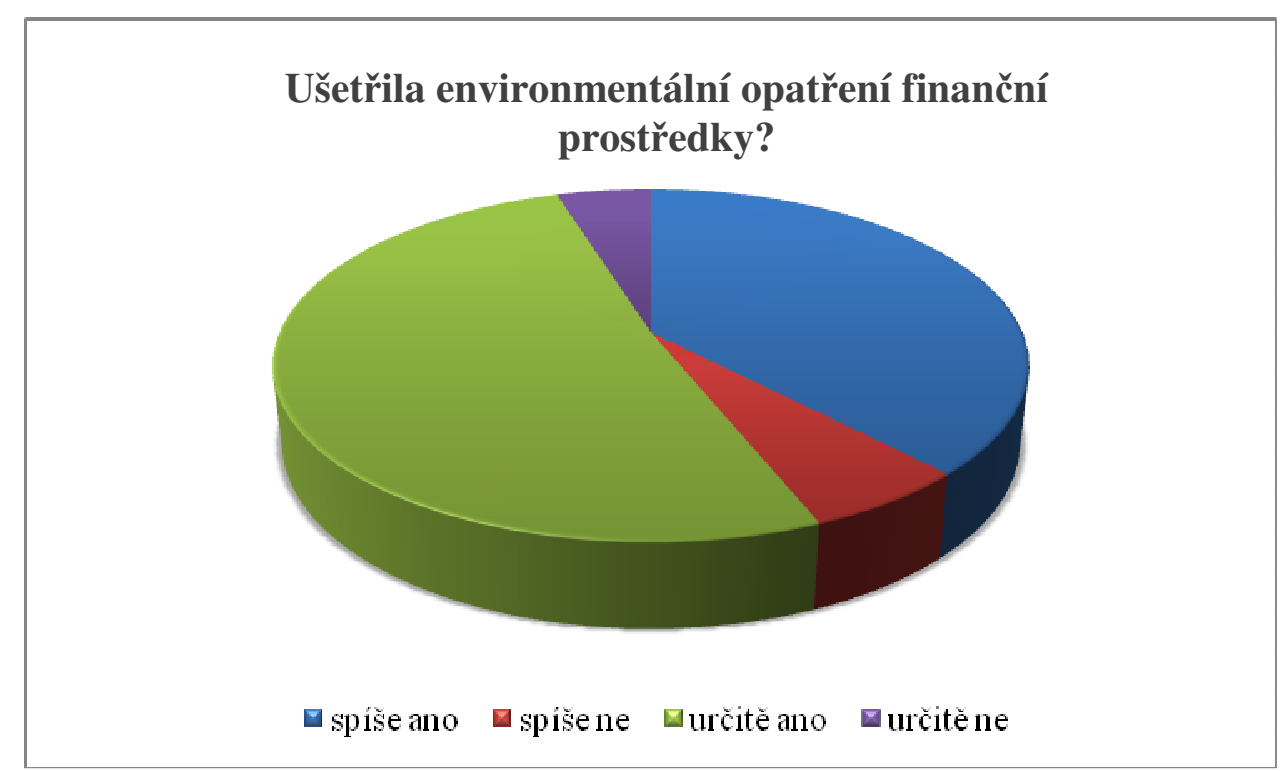

Graf 2: Vliv environmentálních opatření na ekonomickou výkonnost

Z uvedeného grafu je zřejmé, že podnikům z převážné většiny environmentální opatření ušetřila finanční prostředky. Odpověd’ „určitě ano“ zvolilo $34 \%$ podniků, druhou nejčastěji uváděnou odpovědí bylo „spíše ano“, v procentním vyjádření jde o $25 \%$. Tato skutečnost je zcela jistě potěšující, jelikož je důkazem toho, že pokud podniky začnou určitým způsobem sledovat a evidovat jednotlivé environmentální indikátory směrem k jejich eliminaci, dochází k tomu, že navíc dokážou ušetřit určitou část finančních prostředkủ, což je jedině pozitivní. Tuto skutečnost jsme si na základě zodpovězení této otázky pouze potvrdily, jelikož pokud např. podniky snižují spotřebu energií či vody, logicky dochází k tomu, že se šetří také finanční prostředky, vynaložené na tyto složky. Na druhou stranu, podrobné sledování a evidování (a zároveň snižování) environmentálních aspektů dokáže podnikům mnohdy ušetřit peněžní prostředky v oblasti pokut při nedodržení stanovených limitů aj.

\section{Závěr}

Cílem článku je být určitým informačním zdrojem v oblasti environmentální a ekonomické výkonnosti podniků. V první části příspěvku je uveden teoretický přehled, zahrnující jak formy environmentální, tak i ekonomické výkonnosti podniků, ale také vliv environmentálních opatření na ekonomickou výkonnost. Právě ta je velmi často rozhodujícím faktorem při rozhodování o zavedení či zamítnutí různých opatření, které se vztahují k životnímu prostředí. Druhá část tohoto příspěvku je již zaměřena čistě prakticky, jelikož přináší informace ze specifického výzkumu, který byl právě na oblast výkonnosti podniků zaměřen. Informuje nejen o environmentálních indikátorech, které jsou podniky nejčastěji sledovány, ale potvrzuje také skutečnost, že zavedením environmentálních opatření dochází $\mathrm{v}$ rámci činnosti podniků $\mathrm{k}$ šetření finančních prostředků. Tato informace může být pro podniky cenným zjištěním, jelikož právě náklady, související s ochranou životního prostředí, jsou mnohdy předem negativním jevem při zavádění různých opatření. 


\section{Literatura:}

[1] DIXON, J. R., NANNI, A. J., VOLLMANN, T. E. The New Performance Challenge: Measuring Operations for World-class Companies. Dow Jones-Irwin, Homewood, 1990

[2] FISHER, J, Use of Non-Financial Performance Measures. Journal of Cost Management, 1992, 6 (1), pp. 1-8.

[3] HYRŠLOVÁ, J. Účetnictví udržitelného rozvoje podniku. 1.vyd. Praha: Vysoká škola ekonomie a managementu, 2009. 147s. ISBN 978-80-86730-47-9.

[4] ITTNER, C., LARCKER, D., RANDALL, T. Performance implications of strategic performance measurement in financial services firms. Accounting, Organizations \& Society, 2003, 28, 7/8, p. 715.

[5] KOCMANOVÁ, A.; HORNUNGOVÁ, J.; KLÍMKOVÁ, M. Udržitelnost: Integrace environmentální, sociální a ekonomické výkonnosti podniku. 1. vyd. Brno: CERM, 2010. 125 s. ISBN: 978-80-7204-744- 4.

[6] MAŘÍK, M., MAŘÍKOVÁ, P. Moderní metody hodnocení výkonnosti a oceňování podniku: ekonomická přidaná hodnota, tržní přidaná hodnota. 1. vyd. Praha: Ekopress, 2001. 70 s. ISBN 80-86119-36-X.

[7] NOVÁK, J. Marketingový výzkum. 1. vyd. Praha: Grada, 2007, 285 s. ISBN: 80-7248111-1.

[8] NOVÁČEK, K. Podnikový management. 2. vyd. Ostrava:ComputerPress, 2005, 130 s. ISBN 80-7244-111-1.

[9] PAVELKOVÁ, D., KNÁPKOVÁ, A. Výkonnost podniku z pohledu finančního manažera. 2. vyd. Praha: Linde, 2009. 333 s. ISBN 978-80-86131-85-6.

[10]SCHALTEGGER, S., WAGNER, M. Managing Sustainability Performance Measurement and Reporting in an Integrated Manner, Sustability Accounting as the Link between the Sustainability Balanced Scorcared and Sustainability Reporting. Dordrecht: Springer, 2006, 681 - 697s. ISBN -101-4020-4973-0.

[11]SYNEK, M. Nová ekonomika, nové ukazatele. Ekonomika a management [online]. 2008, č. 2 [cit. 2011-12-15]. ISSN 1802-8934. Dostupné z: http://www.ekonomikaamanagement.cz/cz/clanek-nova-ekonomika-nove-ukazatele.html.

[12]SYNEK, M., KOPKÁNĚ, H., KUBÁLKOVÁ, M. Manažerské výpočty a ekonomická analyza. 1. vyd. Praha: C. H. Beck, 2009. 301 s. ISBN 978-80-7400-154-3.

[13] TAUBITZ, M. A. Lean, Green \& Safe. Professional Safety, May2010, Vol. 55 Issue 5, s. $39-46$.

\section{JEL M21}

\section{Ing. Markéta Klímková, Ing. Jana Hornungová}

Vysoké učení technické v Brně

Fakulta podnikatelská

Ústav ekonomiky

Kolejní 2906/4

61200 Brno

klimkova@fbm.vutbr.cz

hornungova@fbm.vutbr.cz 